\title{
SHORT TERM IMPACT OF THE CHILEAN JOURNAL OF AGRICULTURAL RESEARCH: A BIBLIOMETRIC ANALYSIS
}

\author{
Erwin Krauskopf ${ }^{1,2}$
}

\begin{abstract}
In January 2007, the Chilean Journal of Agricultural Research was indexed by the Institute of Scientific Information (ISI). This paper reviews the research that has been published since 2007 by using records extracted from the Web of Science database. The papers published were mostly affiliated to researchers from Chile, and six out of the ten most-contributing countries were from Latin America. The analysis by institutions showed Universidad de Concepcion as the most prolific, although this result is not valid. A lack of standardization in the manner the Instituto de Investigaciones Agropecuarias (INIA) subscribed its address on each paper caused a disaggregation of the information. This was proven by the manual curation of each record that was affiliated to any of the centers belonging to INIA. The journal has a self-citation rate of $19.3 \%$, value that is relatively high if compared to other journals from the same subject category listed on The Journal Citation Reports 2010. Finally, this work should be considered a bibliometric snapshot of the current situation of the journal that will serve as a benchmark when new evaluations are made in a few-years time.
\end{abstract}

Key words: Bibliometric, epistemometry, scientific productivity, Chile.

$I_{s}$ n general, journals that are indexed by the Institute for Scientific Information (ISI) exhibit a high visibility due to the massive use of the Web of Science platform. Undoubtedly, the authors increase their citation rate exponentially as their work is exposed to colleagues working on similar topics all over the world. However, to be indexed by ISI requires that the journals be continuously published (on paper or online) with high quality content. Accordingly, in January 2007 the Chilean Journal of Agricultural Research (formerly known as Agricultura Tecnica) was indexed by ISI under the subject category of "Agriculture, Multidisciplinary" due to its wide scope that covered agriculture, animal production, natural resources, and economics.

In the last decades there has been an increasing interest in using bibliometrics, a scientific and quantitative analysis of publications, to assess the scientific performance of individuals, journals, institutions and countries. Some of the data generated through bibliometric analysis can be utilized to identify key researchers, the development of certain topics over a fixed time period or to what extent journals publish highly cited articles (Hood and Wilson, 2001).

The analysis of one journal and the comparison to others reveals its strengths and weaknesses, information

${ }^{1}$ Universidad Andrés Bello, Facultad de Ciencias Biológicas, República 239, Santiago, Chile.

*Corresponding author (ekrauskopf@unab.cl).

${ }^{2}$ Fundación Ciencia \& Vida, Zañartu 1482, Santiago, Chile.

Received: 4 October 2011.

Accepted: 22 December 2011. that may be used to delineate new objectives by an editorial committee. Hence, in this study the Chilean Journal of Agricultural Research (CJAR) was compared initially to the Spanish Journal of Agricultural Research (SJAR) due to shared attributes such as the number of issues annually published, being edited by similar institutions (in Chile by Instituto de Investigaciones Agropecuarias and in Spain by Instituto Nacional de Investigación y Tecnología Agraria y Alimentaria) and a common cultural background for the researchers of both countries. Thus, the aim of this research was to examine the publication pattern of CJAR focusing on various bibliometric parameters and comparing the results obtained with other journals covering similar research areas.

\section{METHODS}

For the period ranging from January 2007 to August 2011 all records indexed in the Science Citation Index Expanded database from the Web of Science platform were retrieved associated to the Chilean Journal of Agricultural Research (CJAR), Spanish Journal of Agricultural Research (SJAR), Pesquisa Agropecuaria Brasileira (PAB), and Agrociencia. The documents were analyzed according to their type, number of citations, affiliation, and countries of origin. For this study, records that were categorized as "corrections" were discarded. In addition, the 2010 ISI Journal Citation Report (JCR) database was used to obtain the impact factors of the citing journals. 


\section{RESULTS AND DISCUSSION}

Over the 56-mo period, a total of 19 issues (18 regularsand one special issue) had been indexed on the Science Citation Index Expanded database that accounted for 287 papers. The most frequently published document type was "article" that comprised $94.8 \%$ of the total production, followed by "review" (4.5\%), biographical item $(0.35 \%)$ and editorial material $(0.35 \%)$. Table 1 shows the top ten countries in terms of relative contribution to the number of papers published by CJAR. Not surprisingly, Chilean researchers are responsible for more than two thirds of the total amount, being followed by far by Argentina (11.2\%) and the United States (5.9\%). Actually, six out of the 10 countries listed are geographically close to Chile, fact that could imply that the majority of the subjects covered within the scope of the journal are confined to matters related to South American countries. In the case of SJAR (Table 1), only three out of the 10 countries are from the vicinity, being Spain the top contributor to the journal with a percentage of the total papers similar to the case of the Chilean journal. Likewise, Mexico was responsible for supplying three quarters of the papers published on Agrociencia. Attention is drawn to the journal PAB, which is mostly supported by contributions from Brazil (93.4\%), being followed by far by countries such as USA (1.8\%) and France $(1.7 \%)$. This might be due to the fact that during the time-period evaluated, PAB published $75.6 \%$ of the articles in Portuguese, 22.2\% in English and the rest in Spanish.

When the records from CJAR were analyzed by institutions affiliated to the authors of the papers, an interesting result emerged. As Table 2 shows, Universidad de Concepcion turned out as the top contributor as indicated by the retrieved data. Nevertheless, a closer look at Table 2 revealed that six out of the 12 entrees belongeds to the Instituto de Investigaciones Agropecuarias, known as INIA, but were categorized as different institutions due to a lack of standardization in the manner the authors wrote down their affiliation. In fact, after a manual curation of the retrieved records, the new record count for INIA was 77 , corresponding to $26.8 \%$ of the total amount of papers
Table 2. List of institutions affiliated to researchers that have published papers on CJAR, indicating number of papers from each institution and the percentage from the total amount of papers published within the period January 2007 - August 2011.

\begin{tabular}{lcc}
\hline Institution & Record count & $\begin{array}{c}\text { Percentage from } \\
\text { total }\end{array}$ \\
\hline Universidad de Concepción & 52 & 18.1 \\
Universidad de Chile & 35 & 12.2 \\
Universidad de Talca & 26 & 9.1 \\
Universidad Austral de Chile & 21 & 7.3 \\
Ctr Reg Invest Quilamapu & 16 & 5.6 \\
Inst Invest Agropecuarias INIA & 16 & 5.6 \\
Universidad de la Frontera & 16 & 5.6 \\
Inst Invest Agr INIA & 12 & 4.2 \\
Ctr Reg Invest Carillanca & 11 & 3.8 \\
Pontificia Universidad Católica de Chile & 9 & 3.1 \\
Ctr Reg Invest Remehue & 8 & 2.8 \\
Ctr Reg Invest La Platina & 7 & 2.4 \\
\hline
\end{tabular}

published. This inaccuracy undermines the visibility of INIA towards the rest of the world as its research capability seems diminished. The rest of the institutions involved in the publication of their research in CJAR were assessed, but this problem was not detected probably due to their low number of papers published on CJAR.

In order to evaluate the impact of CJAR, it was of interest to identify the most frequently cited papers and the citations generated by the journal as a whole. The number of citations a particular paper or journal receives is a measure of its visibility to other researchers (Krauskopf, 2008). The top five cited papers and their

Table 3. Top five cited papers from Chilean Journal of Agricultural Research.

\begin{tabular}{|c|c|c|c|c|}
\hline Title & Year & Vol. & Pages & $\begin{array}{l}\text { Times } \\
\text { cited }\end{array}$ \\
\hline $\begin{array}{l}\text { Predicting breeding values of population } \\
\text { effect of maize evaluated in Brazil and } \\
\text { Paraguay }\end{array}$ & 2007 & 67 & $139-146$ & 8 \\
\hline $\begin{array}{l}\text { Fungistatic activity of essential oils } \\
\text { extracted from Peumus boldus Mol., } \\
\text { Laureliopsis philippiana (Looser) Schodde } \\
\text { and Laurelia sempervirens (Ruiz \& Pav.) }\end{array}$ & 2009 & 69 & $30-37$ & 7 \\
\hline $\begin{array}{l}\text { Characterization of dairy slurry in Southern } \\
\text { Chile farms }\end{array}$ & 2007 & 67 & $155-162$ & 5 \\
\hline $\begin{array}{l}\text { A Ricardian analysis of the impact of } \\
\text { climate change of South American farms }\end{array}$ & 2008 & 68 & $69-79$ & 5 \\
\hline $\begin{array}{l}\text { Use of the dynamic model for the } \\
\text { assessment of winter chilling in a temperate } \\
\text { and a subtropical climatic zone of Chile }\end{array}$ & 2008 & 68 & $198-206$ & 5 \\
\hline
\end{tabular}

Table 1. Country affiliations to contributors to the Chilean Journal of Agricultural Research, Spanish Journal of Agricultural Research, Pesquisa Agropecuaria Brasileira, and Agrociencia, from 2007 to August 2011.

\begin{tabular}{|c|c|c|c|c|c|c|c|c|c|c|c|}
\hline \multicolumn{3}{|c|}{$\begin{array}{c}\text { Chilean Journal } \\
\text { of Agricultural Research }\end{array}$} & \multicolumn{3}{|c|}{$\begin{array}{c}\text { Spanish Journal } \\
\text { of Agricultural Research }\end{array}$} & \multicolumn{3}{|c|}{$\begin{array}{c}\text { Pesquisa Agropecuaria } \\
\text { Brasileira }\end{array}$} & \multicolumn{3}{|c|}{ Agrociencia } \\
\hline Countries & $\begin{array}{c}\text { Record } \\
\text { count }\end{array}$ & $\begin{array}{c}\text { Percentage } \\
\text { from } \\
\text { total }\end{array}$ & Countries & $\begin{array}{l}\text { Record } \\
\text { count }\end{array}$ & $\begin{array}{l}\text { Percentage } \\
\text { from } \\
\text { total }\end{array}$ & Countries & $\begin{array}{l}\text { Record } \\
\text { count }\end{array}$ & $\begin{array}{l}\text { Percentage } \\
\text { from } \\
\text { total }\end{array}$ & Countries & $\begin{array}{c}\text { Record } \\
\text { count }\end{array}$ & $\begin{array}{l}\text { Percentage } \\
\text { from } \\
\text { total } \\
\end{array}$ \\
\hline Chile & 208 & 72.5 & Spain & 373 & 67.5 & Brazil & 962 & 93.9 & Mexico & 310 & 76.9 \\
\hline Argentina & 32 & 11.2 & Turkey & 34 & 6.1 & USA & 18 & 1.8 & Spain & 35 & 8.7 \\
\hline USA & 17 & 5.9 & Argentina & 30 & 5.4 & France & 17 & 1.7 & USA & 25 & 6.2 \\
\hline Brazil & 15 & 5.2 & Portugal & 17 & 3.1 & Mexico & 11 & 1.1 & Chile & 24 & 6.0 \\
\hline Spain & 12 & 4.2 & Iran & 16 & 2.9 & Spain & 10 & 1.0 & Brazil & 13 & 3.2 \\
\hline Colombia & 11 & 3.8 & USA & 15 & 2.7 & Germany & 8 & 0.8 & Venezuela & 12 & 3.0 \\
\hline Mexico & 10 & 3.5 & Brazil & 14 & 2.5 & Argentina & 7 & 0.7 & Argentina & 8 & 2.0 \\
\hline Germany & 7 & 2.4 & Chile & 14 & 2.5 & Portugal & 7 & 0.7 & France & 7 & 1.7 \\
\hline Uruguay & 4 & 1.4 & Mexico & 13 & 2.4 & Colombia & 6 & 0.6 & Cuba & 5 & 1.2 \\
\hline Pakistan & 4 & 1.4 & Pakistan & 9 & 1.6 & England & 6 & 0.6 & England & 5 & 1.2 \\
\hline
\end{tabular}


Table 4. List of journals that have used Chilean Journal of Agricultural Research as a source of information. The 2010 impact factor was obtained from Journal Citation Report 2010. Eleven journals were not included in this list due to a lack of an IF2010.

\begin{tabular}{|c|c|c|}
\hline Journal title & Citations & IF2010 \\
\hline Current Opinion in Plant Biology & 1 & 9.431 \\
\hline Biosensors \& Bioelectronics & 1 & 5.361 \\
\hline Proceedings of the Royal Society B-Biological Sciences & 1 & 5.064 \\
\hline Environmental Science \& Technology & 1 & 4.825 \\
\hline PLoS ONE & 1 & 4.411 \\
\hline Trends in Food Science \& Technology & 1 & 3.710 \\
\hline Food and Bioprocess Technology & 1 & 3.576 \\
\hline Agricultural and Forest Meteorology & 2 & 3.228 \\
\hline American Journal of Botany & 1 & 3.052 \\
\hline Agriculture Ecosystems \& Environment & 1 & 2.790 \\
\hline Plant and Soil & 1 & 2.773 \\
\hline Industrial Crops and Products & 1 & 2.507 \\
\hline Journal of Dairy Science & 1 & 2.497 \\
\hline Food Research International & 1 & 2.416 \\
\hline Pest Management Science & 3 & 2.313 \\
\hline Plant Cell Reports & 1 & 2.279 \\
\hline Biological Control & 1 & 2.164 \\
\hline Functional Plant Biology & 1 & 2.156 \\
\hline Soil \& Tillage Research & 1 & 2.100 \\
\hline Molecular Biotechnology & 1 & 2.091 \\
\hline Crop Science & 2 & 2.020 \\
\hline Molecules & 1 & 1.988 \\
\hline Nutrient Cycling in Agroecosystems & 1 & 1.957 \\
\hline Food Policy & 1 & 1.873 \\
\hline International Journal of Biometeorology & 1 & 1.805 \\
\hline Journal of Food Science & 2 & 1.733 \\
\hline Environmental Entomology & 1 & 1.534 \\
\hline Physiological Entomology & 2 & 1.417 \\
\hline Livestock Science & 1 & 1.295 \\
\hline Journal of Applied Entomology & 1 & 1.276 \\
\hline Agricultural Economics & 1 & 1.239 \\
\hline Biochemical Systematics and Ecology & 1 & 1.110 \\
\hline Scientia Horticulturae & 2 & 1.045 \\
\hline Journal of Insect Science & 1 & 1.014 \\
\hline Journal of Pest Science & 1 & 0.988 \\
\hline Biosystems Engineering & 1 & 0.983 \\
\hline Animal Welfare & 1 & 0.907 \\
\hline Transactions of the ASABE & 1 & 0.889 \\
\hline Helminthologia & 1 & 0.847 \\
\hline Plant Biosystems & 1 & 0.829 \\
\hline Journal International des Sciences de la Vigne et du Vin & 1 & 0.771 \\
\hline Quimica Nova & 1 & 0.744 \\
\hline Pesquisa Agropecuaria Brasileira & 2 & 0.681 \\
\hline Spanish Journal of Agricultural Research & 1 & 0.646 \\
\hline Allelopathy Journal & 1 & 0.635 \\
\hline Journal of Soil Science and Plant Nutrition & 12 & 0.596 \\
\hline Chemical Industry \& Chemical Engineering Quarterly & 1 & 0.580 \\
\hline $\begin{array}{l}\text { Revista Brasileira de Zootecnia-Brazilian Journal of } \\
\text { Animal Science }\end{array}$ & 2 & 0.557 \\
\hline African Journal of Microbiology Research & 1 & 0.528 \\
\hline Ciencia e Investigacion Agraria & 12 & 0.528 \\
\hline Phytoparasitica & 1 & 0.527 \\
\hline Applied Economic Perspectives and Policy & 1 & 0.523 \\
\hline Crop Breeding and Applied Biotechnology & 1 & 0.509 \\
\hline Journal of Pesticide Science & 1 & 0.500 \\
\hline $\begin{array}{l}\text { Acta Agriculturae Scandinavica Section B-Soil and Plant } \\
\text { Science }\end{array}$ & 1 & 0.460 \\
\hline Tropical Plant Pathology & 1 & 0.448 \\
\hline Journal of Food Agriculture \& Environment & 3 & 0.425 \\
\hline Czech Journal of Food Sciences & 1 & 0.413 \\
\hline Interciencia & 1 & 0.391 \\
\hline Chilean Journal of Agricultural Research & 34 & 0.385 \\
\hline $\begin{array}{l}\text { Boletín Latinoamericano y del Caribe de Plantas } \\
\text { Medicinales y Aromáticas }\end{array}$ & 3 & 0.323 \\
\hline Agrociencia & 3 & 0.294 \\
\hline Journal of Animal and Veterinary Advances & 1 & 0.292 \\
\hline Archivos de Medicina Veterinaria & 2 & 0.240 \\
\hline Bioscience Journal & 1 & 0.203 \\
\hline Ciencia Florestal & 1 & 0.191 \\
\hline Phyton-International Journal of Experimental Botany & 1 & 0.137 \\
\hline Revista Científica-Facultad de Ciencias Veterinarias & 1 & 0.122 \\
\hline Journal of Agricultural and Urban Entomology & 1 & 0.057 \\
\hline Egyptian Journal of Biological Pest Control & 1 & 0.052 \\
\hline
\end{tabular}

citation frequency are listed on Table 3 . The most highranking article on the journal was written by Mora and Scapim (eight citations), followed by a paper authored by Bittner et al. (seven citations) and three other articles, each with five citations. As a matter of fact, these are the five papers that account for the CJAR Hirsch index (h-index = $5)$. This index measures the number of published papers, $N$, that have been cited $N$ or more times (Hirsch, 2005). This parameter has been widely used to estimate the scientific impact of journals, researchers, institutions, and countries. Although this number appears to be low, the h-index for SJAR was 6 even though its most influential paper (published on 2007) has been cited 17 times, and in the case of the journal Agrociencia the h-index $=5$. For $\mathrm{PAB}$, the estimated h-index was 11 , which can be partially explained by the number of issues printed yearly (12 in total) and the average number of papers (approximately 220) published each year.

Regarding the total number of citations perceived by the journal since 2007, CJAR had 176 journal citations as indicated on the Web of Science database in August 2011, from which 34 were self-cites, resulting in a selfcitation rate of $19.3 \%$. In comparison, during the same time period SJAR had 448 journal citations with 65 selfcites (14.5\%), Agrociencia had 255 journal citations with 49 self-cites $(19.2 \%)$ and PAB a total of 1340 journal citations with 413 self-cites (30.8\%). Various studies have focused on the proportion of self-citation in journals. For instance, Falagas and Kavvadia (2006) established that on average a group of biomedical journals contained $19 \%$ of self cites, while Krauss (2007) determined that all the journals categorized by ISI as "ecology" had a mean selfcitation rate of $16.2 \%$. Self-citation is justified when the published research was built on previous results printed in the same journal; nevertheless it is a well-known fact that journal impact factors can be manipulated by forcing self-citation (Yu and Wang, 2007).

Since CJAR is currently categorized as "Agriculture, multidisciplinary", the complete data set for the 55 journals that compose this list was downloaded from JCR2010 and ordered by impact factor from highest to lowest. The journal with the highest impact factor was Agricultural Systems with an IF2010 $=2.907$ and 8.3\% of self-cites considering the same parameters used for CJAR and SJAR, that is, only papers published from January 2007 onwards. On position 28 (mean of the list), the journal JARQ-Japan Agricultural Research Quarterly exhibited an IF2010 $=0.41$ and an $8.6 \%$ self citation rate. From the analyzed journals, PAB $($ IF2010 $=0.687)$ and SJAR (IF2010 $=0.646)$ were ranked within the second quartile of journals on positions 18 and 20 of the journal list, while CJAR (IF2010 $=0.385$ ) and Agrociencia (IF2010 $=0.294$ ) were located on positions 30 and 33 of the list (third quartile). Undoubtedly, the self-citation rate of CJAR, SJAR and Agrociencia seem slightly high as compared to the journals ranked at the top or mean of the 
list. In the case of $\mathrm{PAB}$, the extremely high self-citation rate may be founded on the language bias of the journal.

In order to study in depth this matter, the 176 citing articles were downloaded and their source identified, so I could find out which journals are using CJAR as a source of information. Table 4 summarizes all the journals that have cited papers published on CJAR, which have been assigned a 2010 impact factor. This table reveals the high number of self-citations by CJAR, followed by the Journal of Soil Science and Plant Nutrition (12 cites) and the journal Ciencia e Investigación Agraria (12 cites). The mean impact factor of the citing journals was 0.385 that corresponds to CJAR. It is important to point out that journals such as Current Opinion in Plant Biology, Proceedings of the Royal Society B-Biological Sciences, and PLoS ONE have began using CJAR as a source of information on which to substantiate their findings, evidence that confirms the high-quality research being published by the journal.

\section{CONCLUSIONS}

The incorporation of any journal onto the Web of Science database serves a double purpose. First, it validates the quality of the information published on a journal over a certain level of threshold and it also increases the journal visibility to other users. In the particular case of CJAR, the fact that papers of interest are downloadable free-ofcharge benefits the researchers and the general public. Since 2007, CJAR has shown to be a valuable repository for researchers from Latin America as shown on this study. In fact, most of the Latin American countries (including Chile) involved in agricultural research have published in the journal more than a few times. In addition, the quality of the papers published as been increasing through time as journals with high impact factor have began using CJAR as a source of information

Finally, this work is a bibliometric snapshot of the current situation of CJAR that will serve as a benchmark that could be easily surpassed in 3-5 yr by good management from the editorial team and the reviewers. Regrettably, no straightforward method can be suggested to achieve this, besides more emphasis on the manuscript reviewing process.
Impacto de corto plazo de Chilean Journal of Agricultural Research: Un análisis bibliométrico. En enero 2007, la revista Chilean Journal of Agricultural Research fue indexada por el Institute of Scientific Information (ISI), por lo que este artículo analiza la investigación que ha sido publicada desde el año 2007 utilizando los registros extraídos de la base de datos Web of Science. Los artículos publicados fueron mayormente afiliados a investigadores de Chile, siendo seis de los 10 países que más contribuyeron en artículos de Latinoamérica. Un análisis por institución mostró a la Universidad de Concepción como la más prolífica, aunque este resultado no es válido por una ausencia de estandarización en la manera que el Instituto de Investigaciones Agropecuarias (INIA) suscribe su dirección en cada artículo, lo que provoca disgregación de la información. Esto se verificó mediante la curación manual de cada registro que se encontraba afiliado a cualquiera de los centros que pertenecen a INIA. Esta revista tiene un grado de auto-citas de $19.3 \%$, valor relativamente alto si se compara con revistas de la misma categoría de tópico que se encuentran listadas en Journal Citation Report 2010. Finalmente, este trabajo debe ser considerado como una visión bibliométrica de la situación actual de la revista que servirá como línea base para nuevas evaluaciones a realizarse en pocos años más.

Palabras clave: Bibliometría, epistemometría, productividad científica, Chile.

\section{LITERATURE CITED}

Falagas, M.E., and P. Kavvadia. 2006. Eigenlob: Self-citation in biomedical journals. Federation of American Societies for Experimental Biology Journal 20:1039.

Hirsch, J.E. 2005. An index to quantify an individual's scientific research output. Proceedings of National Academy of Science USA 102:16569-16572.

Hood, W.W., and C.S. Wilson. 2001. The literature of bibliometrics, scientometrics and informetrics. Scientometrics 52:291-314.

Krauskopf, E. 2008. Plant science research productivity in Chile during the past 20 years. Biological Research 41:137-141.

Krauss, J. 2007. Journal self-citation rates in ecological sciences. Scientometrics 73:79-89.

Yu, G., and L. Wang. 2007. The self-cited rate of scientific journals and the manipulation of their impact factors. Scientometrics 73:321-330. 